\title{
Overview of ovarian masses
}

\section{R. Padma Priya, K. P. Mohana Sundari*, R. Aruna Rani}

\begin{abstract}
Department of Obstetrics and Gynecology, Government Mohan Kumaramangalam Medical College, Salem, Tamil
\end{abstract} Nadu, India

Received: 15 September 2016

Accepted: 07 October 2016

\section{*Correspondence:}

Dr. K. P. Mohana Sundari,

E-mail: m72sundari@yahoo.in

Copyright: (C) the author(s), publisher and licensee Medip Academy. This is an open-access article distributed under the terms of the Creative Commons Attribution Non-Commercial License, which permits unrestricted non-commercial use, distribution, and reproduction in any medium, provided the original work is properly cited.

\begin{abstract}
Background: To study the incidence, clinical presentation and histopathological pattern of ovarian masses in patients attending Department of gynaecology in a tertiary center in Tamil Nadu.

Methods: Retrospective analysis of 77 cases from March 2015 to March 2016.

Results: The total incidence of ovarian masses was $8.5 \%$. Among the ovarian masses $23.37 \%$ were non-neoplastic lesions and $71.4 \%$ were benign, $3.6 \%$ were borderline and $21.8 \%$ were malignant. All the malignant tumours were seen between 30-60yrs of age.

Conclusions: Ovarian neoplasms were thrice the incidence of non-neoplasm. Among the neoplastic lesion, benign neoplasms were common and the commonest was serous cystadenoma and the commonest malignant tumour was serous cyst adenocarcinoma.
\end{abstract}

Keywords: Ovarian tumour, Serous cystadenoma, Serous cystadenocarcinoma

\section{INTRODUCTION}

The origin and pathogenesis of ovarian cancer has perplexed investigations for decades. The incidence of ovarian tumours is increasing in developing countries. ${ }^{1,2}$ Ovarian tumours account for $30 \%$ of all cancers of female genital tract. ${ }^{3}$ Ovarian malignancy ranks fifth in cancer death worldwide and in India it ranks third among the female genital tract malignancies. ${ }^{1}$ A female risk at birth of having ovarian tumour in her life time is 6-7\% and having ovarian cancer is almost $1.5 \%$ and dying from ovarian cancer is $1.0 \%{ }^{4}$ Indian cancer registry data project ovary as an important site of cancer in women, comprising upto8.75of cancers. ${ }^{5}$ Ovarian tumours are insidious in onset and usually diagnosed at a later stage. The complex histology and the anatomical location of ovary are responsible for the late presentation and its management difficulties. Hence a high index of suspicion is always needed. Biochemical markers and radiological assistance help in early diagnosis. Diverse histopathology is common in ovarian lesions and hence diagnosing the specific histological type is important in offering treatment. So, this study has been done to analyse the age distribution, presenting symptoms and the various histopathological types of ovarian tumours in patients who underwent surgical management.

\section{METHODS}

This is the retrospective analysis of patients with the ovarian masses from March 2015 to March 2016 at Government Mohan Kumaramangalam Medical College Hospital, Salem, Tamilnadu, India. All patients who were surgically managed are included in this study. Those patients who are conservatively managed and those with non-ovarian masses were excluded from this study. The details such as age, presenting symptoms, surgical details and histopathological reports were noted. Based on the HPE reports ovarian malignancies were analysed. 


\section{RESULTS}

Table 1: Age distribution of ovarian masses $(n=77)$.

\begin{tabular}{|lll|}
\hline Age (Years) & No. of cases & Percentage \\
\hline$<20$ & 3 & $3.9 \%$ \\
\hline $21-30$ & 16 & $20.8 \%$ \\
\hline $31-40$ & 17 & $22.1 \%$ \\
\hline $41-50$ & 21 & $27.2 \%$ \\
\hline $51-60$ & 30 & $16.9 \%$ \\
\hline $61-70$ & 6 & $7.8 \%$ \\
\hline$>70$ & 1 & $1.3 \%$ \\
\hline
\end{tabular}

Out of the total admissions of 900 patients in gynaec ward,77 patients presented with ovarian masses with a incidence of $8.5 \%$.Age distribution of cases of ovarian mass was between 20-70 yrs in our study. The maximum number of ovarian mass was presented in the age group of 21-50 yrs. Based on the clinical presentation, most of the patients presented with pain abdomen 50 (64\%), mass abdomen 15 (19\%) followed by abdominal symptoms 10 (12\%). Among the ovarian masses 18 (23.37\%) were of non neoplastic lesion. Out of the neoplastic lesion
$41(74.5 \%)$ were benign, $2(3.6 \%)$ borderline and $12(21.8 \%)$ were malignant. The commonest malignant tumour was serous cystadenocarcinoma $6(50 \%)$ followed by mucinous cystadenocarcinoma 4 (33\%).

Among the entire benign lesion (41) the commonest histological type was surface epithelial tumours followed by Germ cell tumour. Least common lesion was dysgerminoma and mixed germ cell tumour.

Table 2: Distribution of various types of nonneoplastic ovarian lesions $(n=18)$.

\begin{tabular}{|ll|}
\hline Non-neoplastic lesions & No. of cases \\
\hline Follicular cyst & 4 \\
\hline Luteal cyst & 2 \\
\hline Simple serous cyst & 1 \\
\hline Hemorrhagic cyst & 2 \\
\hline Endometriotic cyst & 3 \\
\hline Oophoritis & 2 \\
\hline Paraovarian cyst & 1 \\
\hline Miscellaneous & 3 \\
\hline
\end{tabular}

Table 3: Comparison of the histopathological pattern of ovarian masses.

\begin{tabular}{|c|c|c|c|c|c|c|}
\hline Histopathology & Our study & Sharadha et $\mathrm{al}^{8}$ & Manivasagan et $a^{12}$ & Mondal et al $^{11}$ & Pilli et $\mathbf{a l}^{9}$ & Jha et $a^{10}$ \\
\hline \multicolumn{7}{|l|}{ Benign } \\
\hline Serous & $48.8 \%$ & $67 \%$ & $59.5 \%$ & $29.9 \%$ & $42.9 \%$ & $32.6 \%$ \\
\hline Mucinous & $39 \%$ & $19 \%$ & $29 \%$ & $11.1 \%$ & $25.5 \%$ & $15.6 \%$ \\
\hline Dermoid & $7.3 \%$ & $11.6 \%$ & $14 \%$ & $15.9 \%$ & $17 \%$ & $48 \%$ \\
\hline \multicolumn{7}{|l|}{ Malignant } \\
\hline Serous & $50 \%$ & $42.9 \%$ & - & $11.3 \%$ & - & $46.2 \%$ \\
\hline Mucinous & $33.3 \%$ & $28.6 \%$ & - & $3.3 \%$ & - & $23 \%$ \\
\hline
\end{tabular}

\section{DISCUSSION}

Age range of our subjects was from 20 to 70 yrs. In our study, the maximum incidence of ovarian masses was between 21 to $50 \mathrm{yrs}$ of age. This differs from the western data where it is between 50 and 70 yrs. $^{7}$ Abdominal pain followed by mass abdomen and abdominal symptoms were common clinical presentation in our study comparable to Sharadha et al study (18). The incidence of the ovarian masses was about $8.5 \%$.Out of the ovarian masses (77), the non-neoplastic ovarian masses was $23.37 \%(18 / 77)$ and the neoplastic ovarian mass was $71.4 \%$ (55/77). Among the neoplastic lesions $74.5 \%$ $(41 / 55)$ were benign, $21.8 \%$ (12/55) were malignant and $3.6 \%(2 / 55)$ were border line. These were comparable to Pilli et al study and Jha et al (9/10).

Out of the benign tumours, serous cystadenoma accounted for $49 \%$; mucinous cystadenoma $39 \%$; germ cell tumours $7.3 \%$; sex cord tumours $4.9 \%$ which was comparable to study done by Pilli et al but differs from Mondel et al and Jha et al. ${ }^{9-11}$

In our study, mucinous tumours were on the rising trend comparable to the study done by Jha et al. ${ }^{10}$ Of all the malignant tumours serous cystadenocacinoma accounted for $50 \%$ followed by mucinous cystadenocarcinoma $33.3 \%$ which is comparable to study done by Sharadha et al and Pilli et al. ${ }^{8,9}$ All the malignant ovarian tumours were presented between 30-60 yrs of age and the maximum occurrence was between 41-50 yrs. One case of dysgerminoma presented at 35 yrs of age. One case of mixed germ cell tumour presented at 65 yrs of age.

\section{CONCLUSION}

Benign tumours were more common than the malignant ovarian tumours. Surface epithelial tumours are most common histological type in both benign and malignant tumours. Overall serous cystadenoma is the most 
common benign and serous cystadenocarcinoma is the most common malignant tumour. Mucinous cystadenoma and mucinous cystadenocarcinoma are in the rising trend.

Funding: No funding sources

Conflict of interest: None declared

Ethical approval: The study was approved by the Institutional Ethics Committee

\section{REFERENCES}

1. Parkin DM, Whelan SL, Ferlay J, Raymond L, Young J. Cancer Incidence in Five Continents 1997. VII. Lyon France: International Agency for Research on Cancer and International Association of Cancer Registries; IARC Scientific Publications No. 143. 1997.

2. Pisani P. Burden of cancer in developing countries. IARC Scientific Pub. 1994;129:31-9.

3. Umadevi K. Current status Of Gynaecological Cancer Case in India. J. Gynaec Oncol. 2009;20(2):77-80.

4. Scuklly RE, Young RH, Clement PB. Atlas of tumour pathology: Third series, Fascicle 23 Washington, DC: Armed forces Institute of Pthology; 1998 .

5. Murthy NS, Shalini S, Suman G, Pruthvisinh S, Methew A. A changing trend in incidence of ovarian
cancer-Indian scenario. Asian Pac J Cancer Prev. 2009;10:1025-30.

6. Shahin R, Ghulam S, Abid A. A clinicopathological study of ovarian cancer. Mothers Child. 1998;36:117-25.

7. Aria M, Utsunomiya, Miki Y. Familial breast and ovarian cancers. Int J Clin Oncol. 2004;9:270-82.

8. Sharadha SO. Sridevi TA. Ovarian Masses: Changing Clinicohistopathological Trends. The journal of Obstetrics and gynaecology of India 2015;65(1);34-8.

9. Pilli GS, Suneeta KP. Ovarian tumours: A study of 282 cases. J. Indian medical association. 2002;100:420,423-7.

10. Jha R, Karki S. Histological pattern of ovarian tumors and their age distribution. Nepal Med Coll J. 2008;10(2):81-5.

11. Mondal SK, Banyopadhayay R, Nag DR. Histologic pattern, bilaterality and clinical evaluation of 957 ovarian neoplasm: A 10 year study in a tertiary hospital of eastern India. J cancer Res Ther. 2011;7(4)433-7.

12. Manivasakan J. A study of benign adnexal masses. Int. J Reprod Contracept Obstet Gynaecol, 2012;1(1):12-6.

Cite this article as: Priya RP, Sundari KPM, Rani RA. Overview of ovarian masses. Int J Reprod Contracept Obstet Gynecol 2016;5:3770-2. 